\title{
Land-use and Land-cover Analysis of Kaduna South Local Government Area, Kaduna State, Nigeria
}

\author{
Cyril Kanayochukwu Ezeamaka ${ }^{1}$, Mwanret Gideon Daful ${ }^{1}$, Emmanuel Chinenelum Umeano ${ }^{2}$ \\ ${ }^{1}$ Department of Geography, Nigeria Defence Academy, Kaduna, Nigeria \\ ${ }^{2}$ Electre Surveying Engineering Service, Dubai, UAE
}

Email address:

cyrilezeamaka@gmail.com (C. K. Ezeamaka)

\section{To cite this article:}

Ezeamaka Cyril Kanayochukwu, Daful Mwanret Gideon, Umeano Emmanuel Chinenelum. Land-use and Land-cover Analysis of Kaduna South Local Government Area, Kaduna State, Nigeria. American Journal of Environmental Protection. Vol. 8, No. 3, 2019 , pp. $62-71$. doi: 10.11648/j.ajep.20190803.11

Received: June 14, 2019; Accepted: July 16, 2019; Published: July 26, 2019

\begin{abstract}
This study assessed the land-use and land-cover changes of Kaduna South LGA, Kaduna State within the period of 30 years (1987 to 2016). Remote Sensing and Geographic Information System approach was employed in the study, where Landsat 5, 7, and 8 series images of 1987, 2001, and 2016 were classified into four categories; built-up, agricultural, vegetation, and water-body. The classification results, after accuracy assessment, provided the LULC makeup statistics at each epoch. The image classification results were crossed to ascertain the transitions between the study epochs. ERDAS Imagine 14.0 was used for the image bands combination, subset, classification and accuracy assessment while the analysis, manipulation and presentation were executed in ArcMap 10.3. The study revealed that the built-up land increased from 26.71\% in 1987 to $59.41 \%$ in 2016 , while agricultural land decreased from $44.14 \%$ to $11.56 \%$ in 2016 . Water-body increased from $0.77 \%$ to $0.78 \%$ over the period. Also observed that vegetation increased from $28.38 \%$ to $31.36 \%$, and then decreased to $28.25 \%$ in 2016 . Therefore, the study recommends that land use/land cover change studies should be carried out and updated annually as it forms a basis for planning and decision making towards environmental sustainability.
\end{abstract}

Keywords: Classification, Change, Land-use, Land-cover, Vegetation, Water-body

\section{Introduction}

Land use and land cover (LULC) change is an inevitable phenomenon occurring both temporary and (or) permanent interest of the inhabitants. This could be either in a small or large scale but the most interesting and fundamental observation is that change occurs over time. Land-use and land-cover change is the change in the physical as well as biological characteristics of land [1]. Land-cover change detection has become an essential component, while studying any area for conservation and recovery purposes. The field of LULC change detection has been drawing the attention of many researchers with the advancement in the field [2]. The knowledge of LULC changes is very important in understanding natural resources, their utilization, conservation and management [3]. Nigeria must have adequate information on many complex interrelated aspects of its environmental activities to make decisions. Land use is only one such aspect, but the knowledge about Land-use and
Land-cover has become increasingly important as the nation plans to overcome problems of haphazard uncontrolled developments deteriorating environmental quality, loss of agricultural land, destruction of wetlands and loss of wildlife habitat. In many countries, Land use and Land cover data are needed by agencies for water resource inventory, flood control, water supply planning, and wastewater treatment [4].

According, land use and land cover are distinct yet closely linked characteristics of the earth's surface [5]. Land use is any form of activity that the land is put to like building construction, forestry and agriculture, while land-cover denotes the physical or natural state of the earth's surface [6]. Land cover originally refers to the kind and state of vegetation, such as forest or grass cover but it has broadened in subsequent usage to include other things such as human structures, soil type, biodiversity, surface and ground water [5]. Human need of land resources gives rise to land use, which varies with the purposes it serves in terms of raw materials, shelter, food, and recreation. As human population increases so does the 
activities increases and the society depends on these activities for its survival. Earlier studies have shown that only few landscapes on the earth are still in their natural state. LULC is a general term that indicates modification of the earth's terrestrial surface. In the last two centuries, the impact of human activities on the land has grown enormously, altering entire landscapes, and ultimately impacting the earth's nutrient and hydrological cycles as well as climate [7].

These changes cannot be well understood without the knowledge of land-use changes that drives them. Knowledge about land-use/cover dynamics is becoming important for continuous planning to overcome the problems of uncontrolled development and deteriorating of biodiversity or environmental quality as a whole $[8,9]$.

The integration of Remote Sensing (RS) and Geographic Information System (GIS) provides a scientific means to build a reliable land use and land cover information system. The LULC information system can be updated as the environment experiences changes from time to time [10]. Studies have shown that remote sensing techniques is technologically more efficient than ground-based data gathering methods and has a number of benefits in gathering information that make it a good tool in environmental management and monitoring [10-12]. Remote sensing techniques is more cost saving method of acquiring raw data to update available information, it has provided an opportunity to obtain first generation information on various aspects of earth resources such as land use and land cover [13].

\section{Literature Review}

Land use and Land cover in Ilorin was analyzed between 1972 and discovered rapid growth in built-up land between 1972 and 1986 while the periods between 1986 and 2001 witnessed a reduction in this class. It was also observed that change by 2015 might likely follow the trend in 1986/2001 [14]. The study on change detection and desertification based on multi-temporal satellite data in Kashan Playa, Iran. Two Landsat TM/ETM+ satellite images of 12 years period (1990-2002) and field observations employed for mapping the extent and monitoring of the desert. The results revealed that about $35 \%$ of the study area is mostly salty lands and fixed sand has changed rapidly. The overall rate changes of the desert lands and vegetation are about 7275 and 62 Ha year-1 respectively [15].

Similarly, other study analyzed and characterized Land cover and its changes in Avellino, Southern Italy (19542004) [16]. Remote sensing (RS) data and techniques with GIS was used. A multi temporal set of imageries was processed, aerial photos (1954), and landsat scenes (MSS 1975, TM 1985 and 1993, ETM+2004). The result showed that LC pattern and its changes are linked to both natural and social processes whose driving role has been clearly demonstrated in the case study. In the same vein, land cover changes occurring between 1975 and 1990 in West Africa was examined using a systematic sample of satellite imagery. The primary data sources for the Land Cover classification were Landsat Multi-spectral scanner (MSS) for 1975 and Landsat Thematic Mapper (TM) for the 1990 period. The result revealed that in 1975 , about $6 \%$ of West Africa was covered by dense tree cover complemented with $12 \%$ of tree cover mosaic. Scholars had studied LULC using remote sensing data and GIS to have great potentials for providing a cost effective, timely, up-to-date and reliable information on land use and land cover changes. LULC changes are effects of human social and economic intervention on the land cover in a landscape $[7,10,12,18-25]$.

\section{Study Area}

Kaduna South Local Government Area is in Kaduna State, Nigeria. Its headquarter is located in Makera. It has an area of $59 \mathrm{~km}^{2}$ and a population of 402,731 as at the 2006 census [26]. It is geographically located within Latitudes $10^{\circ} 25^{\prime}$ $30^{\prime \prime}$ to $10^{\circ} 34^{\prime} 00^{\prime \prime}$ and Longitudes $07^{\circ} 22^{\prime} 30^{\prime \prime}$ to $07^{\circ} 27^{\prime} 30^{\prime \prime}$ of the Greenwich Meridian. Kaduna South LGA Shares boundaries with Chikun LGA towards the south-east and south-west towards the north-east it shares boundary with Kaduna North LGA and towards the north-west it shares boundary with Igabi LGA as shown in Figure 1.

\section{Method and Materials}

This study employed Remote Sensing data and Geographic Information System (GIS) techniques for data acquisition and analysis. A set of pre-processed and spatially referenced multi spectral and multi temporal imageries was used. These Imageries are of the Landsat series; Landsat 5 TM (Thematic Mapper) imagery of the year 1987; the Landsat 7 ETM+ (Enhanced Thematic Mapper Plus) of the year 2001; the Landsat 8 OLI (Operational Land Imager) of the year 2016. All having same path and row of 189 and 53 respectively, a maximum cloud cover of $0.00 \%$, a spatial resolution of $30 \mathrm{~m}$ and all in one scene. Maps were collected from Office of the Surveyor General of the Federation (OSGOF) and Kaduna Geographic information services (KADGIS). The 2006 population figure was obtained from NPC office in Kaduna. Ground truthing data was collected from selected areas within the study area. This enabled the study to update information and ensured that the right locations were used on the imageries.

A supervised classification was carried out on the subset satellite imageries. In recognition of the classification schemes provided by [4] Anderson, J. R., Ernest, E. H., John, T. R. and Richard, E. W. [4], four classes of land cover were identified; built-up land, agricultural land, water-body, and vegetation. In the False Composite imageries, Built-up areas were represented in Cyan color, agricultural land in brown patches, water-body in blue color, and vegetation in thick red color. The reference points overlaid on the classification for the accuracy assessment were collected from the field, through visual interpretation of the imageries, and with the use of Google Earth's high-resolution image. The points were well distributed over the study area for the best accuracy assessment result. One hundred and fifty points were selected randomly for the four LULC classes. 


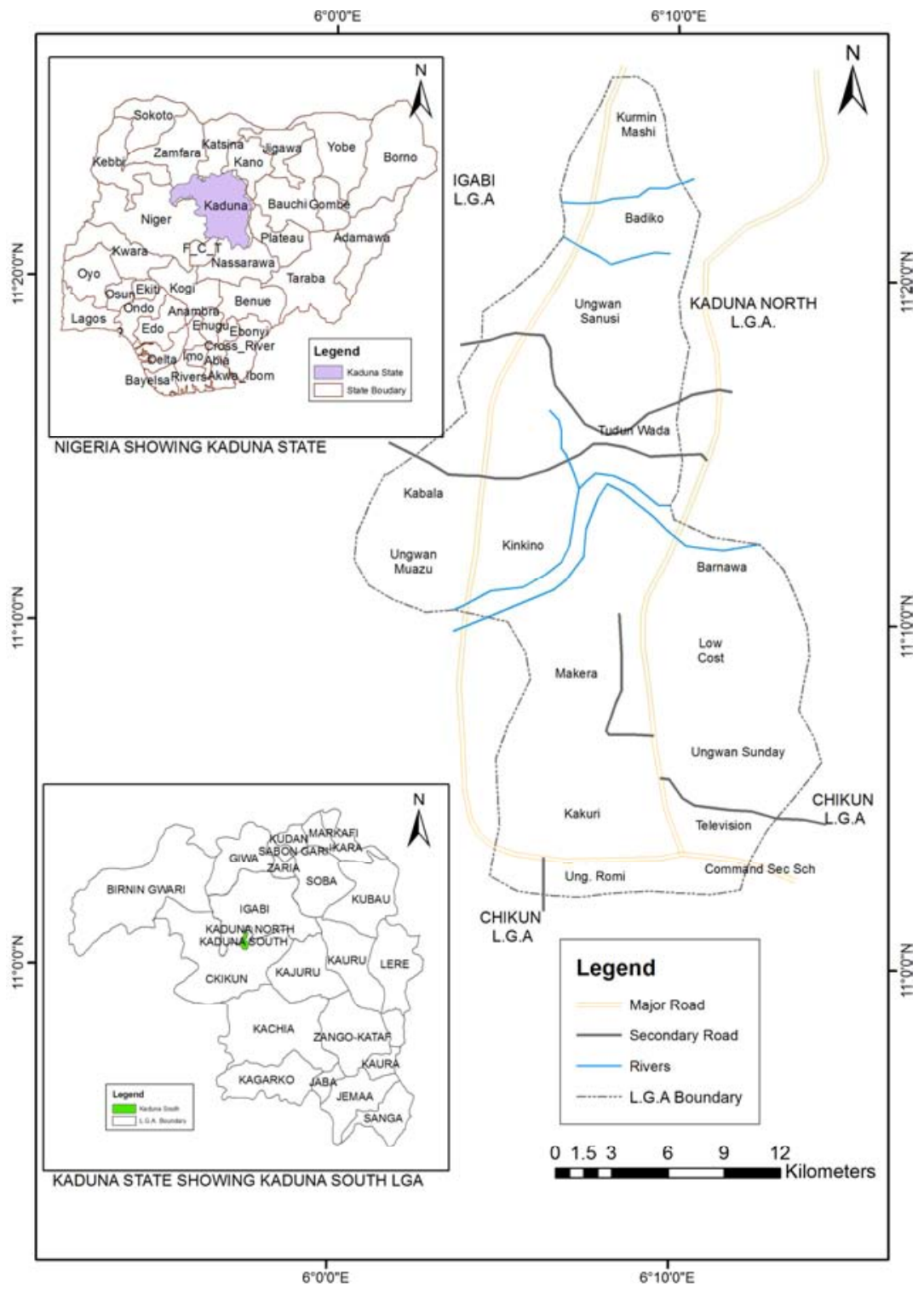

Figure 1. Study Area Map.

\section{Results}

LULC Classification and Accuracy Assessment: The overall classification accuracy of 0.9867 and overall Kappa statistics of 0.9805 for the 1987 image classification represents a satisfactory classification result as shown in
Table 1. As provided above vegetation area has a user's accuracy of $96 \%$ because two of its reference cells were classified as cells for water-body and built-up land. Agricultural lands, water-body and built-up lands recorded $100 \%$ user's accuracy because all reference cells for the classes were classified as same.

Table 1. Error Matrix and Accuracy Assessment Results for 1987 Image Classification.

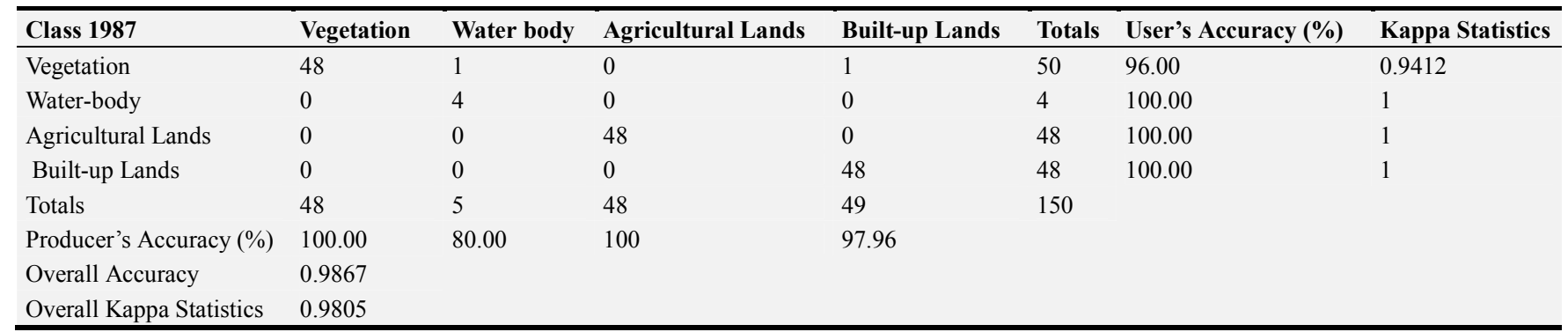

Source: Fieldwork (2018) 
The overall classification accuracy of 0.9533 and overall Kappa statistics of 0.9318 for the 2001 image classification which represents a satisfactory classification result. As provided above vegetation area has a user's accuracy of $98 \%$ because one of its reference cells was classified as cell for
Agricultural Land. Agricultural lands have the users accuracy of $88 \%$ because six of its reference cells were classified as cells for built-up lands. Water-body and built-up lands recorded $100 \%$ user's accuracy because all reference cells for the classes were classified as shown in Table 2.

Table 2. Error Matrix and Accuracy Assessment Results for 2001 Image Classification.

\begin{tabular}{llllllll}
\hline Class 2001 & Vegetation & Water body & Agricultural Lands & Built-up Lands & Totals & User's Accuracy (\%) & Kappa Statistics \\
\hline Vegetation & 49 & 0 & 1 & 0 & 50 & 98.00 & 0.9703 \\
Water-body & 0 & 4 & 0 & 0 & 4 & 100.00 & 1 \\
Agricultural Lands & 0 & 0 & 44 & 6 & 50 & 88.00 & 0.8286 \\
Built-up Lands & 0 & 0 & 0 & 46 & 46 & 100.00 & 1 \\
Totals & 49 & 4 & 45 & 52 & 150 & & \\
Producer's Accuracy (\%) & 100.00 & 100.00 & 97.78 & & & & \\
Overall Accuracy & 0.9533 & & & & & & \\
Overall Kappa Statistics & 0.9318 & & & & & & \\
\hline
\end{tabular}

Source: Fieldwork (2018)

The overall classification accuracy of 0.9467 and overall Kappa statistics of 0.9031 for the 2016 image classification represents a satisfactory classification result. The vegetation area has a user's accuracy of $84.62 \%$ because four of its reference cells were classified as cells for agricultural land and two were classified as water-body as shown in Table 3.
Agricultural lands have a users accuracy of $88.89 \%$ because two of its reference cells were classified as cells for built-up lands. Water-body and built-up lands recorded 100\% user's accuracy because all reference cells for the classes were classified as same.

Table 3. Error Matrix and Accuracy Assessment Results for 2016 Image Classification.

\begin{tabular}{llllllll}
\hline Class 2016 & Vegetation & Water body & Agricultural Lands & Built-up Lands & Totals & User's Accuracy (\%) & Kappa Statistics \\
\hline Vegetation & 33 & 2 & 4 & 0 & 39 & 84.62 & 0.8028 \\
Waterbody & 0 & 2 & 0 & 0 & 4 & 100.00 & 1 \\
Agricultural Lands & 0 & 0 & 16 & 2 & 18 & 88.89 & 0.8718 \\
Built-up Lands & 0 & 0 & 0 & 91 & 91 & 100.00 & 1 \\
Totals & 33 & 4 & 20 & 93 & 150 & \\
Producer's Accuracy (\%) & 100.00 & 50.00 & 80.00 & & & & \\
Overall Accuracy & 0.9467 & & & & & & \\
Overall Kappa Statistics & 0.9031 & & & & & & \\
\hline
\end{tabular}

Source: Fieldwork (2018)

LULC Change Detection: Built-up landuse increased from $1575.89 \mathrm{Ha}(26.71 \%)$ in 1987 to $1803.04 \mathrm{Ha}(30.56 \%)$ in 2001 and to $3516.40 \mathrm{Ha}(59.60 \%)$ in 2016 . Within the same period (1987 to 2001 and to 2016), Agricultural land use decreased from $2604.26 \mathrm{Ha}(44.14 \%)$ to $2160.58 \mathrm{Ha}(36.62 \%)$ and to $670.83 \mathrm{Ha}(11.37 \%)$. Vegetation increased from $1674.42 \mathrm{Ha}$ $(28.38 \%)$ in 1987 to $1850.24 \mathrm{Ha}(31.36 \%)$ in 2001 and in 2016 vegetation decreased to $1666.73 \mathrm{Ha}(28.25 \%)$ while, Water-body increased from $45.43 \mathrm{Ha}(0.77 \%)$ to $86.14 \mathrm{Ha}$
$(1.45 \%)$ and then decreased to $46.02 \mathrm{Ha}(0.78 \%)$ from 1987 to 2001 and then to 2016 respectively as shown in Table 4 and depicted in Figure 2, 3 and 4. The decrease in agricultural land and vegetation was a result of their transitions to the built-up land use, while the increase in water-body can be attributed to the increase in impervious surfaces within the study area, which causes more water runoffs to flow into the water-body.

Table 4. LULC Change Statistics/Percentage between 1987, 2001, and 2016.

\begin{tabular}{|c|c|c|c|c|c|c|c|c|}
\hline \multirow{2}{*}{ LULC CLASSES } & \multicolumn{2}{|l|}{1987} & \multicolumn{2}{|l|}{2001} & \multicolumn{2}{|l|}{2016} & \multicolumn{2}{|c|}{ 1987-2016 } \\
\hline & Area & $\%$ & Area & $\%$ & Area & $\%$ & Area & $\%$ \\
\hline Water-body & 45.43 & 0.77 & 86.14 & 1.46 & 46.95 & 0.795762712 & 1.52 & 0.03 \\
\hline Vegetation & 1674.42 & 28.38 & 1850.24 & 31.36 & 1672.72 & 28.35118644 & -1.70 & -0.03 \\
\hline Built-Up Lands & 1575.89 & 26.71 & 2160.58 & 36.62 & 3508.69 & 59.46932203 & 1932.80 & 32.76 \\
\hline Agricultural Lands & 2604.26 & 44.14 & 1803.04 & 30.56 & 671.64 & 11.38372881 & -1932.62 & -32.76 \\
\hline Total & 5900.00 & 100.00 & 5900.00 & 100.00 & 5900.00 & 100.00 & 0.00 & 0.00 \\
\hline
\end{tabular}

Source: Fieldwork (2018) 
The extent of LULC conversions that has taken place within the study period as shown in Table 5 . This reveals that Agricultural land use was majorly converted to built-up land by $2019.76 \mathrm{Ha}$ and Vegetation to Built-up land by $7.30 \mathrm{Ha}$.
Looking at the major and minor LULC transitions which took place within the period of study, it can be said that the study area has experienced environmental changes as shown in Figure 5.

Table 5. LULC Transitions from 1987 to 2016.

\begin{tabular}{lllllll}
\hline \multirow{2}{*}{ LULC Classes } & & $\mathbf{2 0 1 6}$ & & & \\
\cline { 3 - 7 } & & Water-body (Ha) & Vegetation (Ha) & Built-Up Lands (Ha) & Agricultural lands (Ha) & Total \\
\hline \multirow{4}{*}{1987} & Water-body & 31.422 & 11.785 & 2.190 & 0.033 & 45.430 \\
& Vegetation & 15.500 & 851.711 & 679.872 & 127.337 & 1674.420 \\
& Built-Up Lands & 0.011 & 69.289 & 1462.776 & 43.814 & 1575.890 \\
& Agricultural Lands & 0.021 & 739.930 & 1363.856 & 500.453 & 2604.260 \\
& Total & 46.955 & 1672.716 & 3508.693 & 671.637 & 5900.000 \\
\hline
\end{tabular}

Source: Fieldwork (2018)

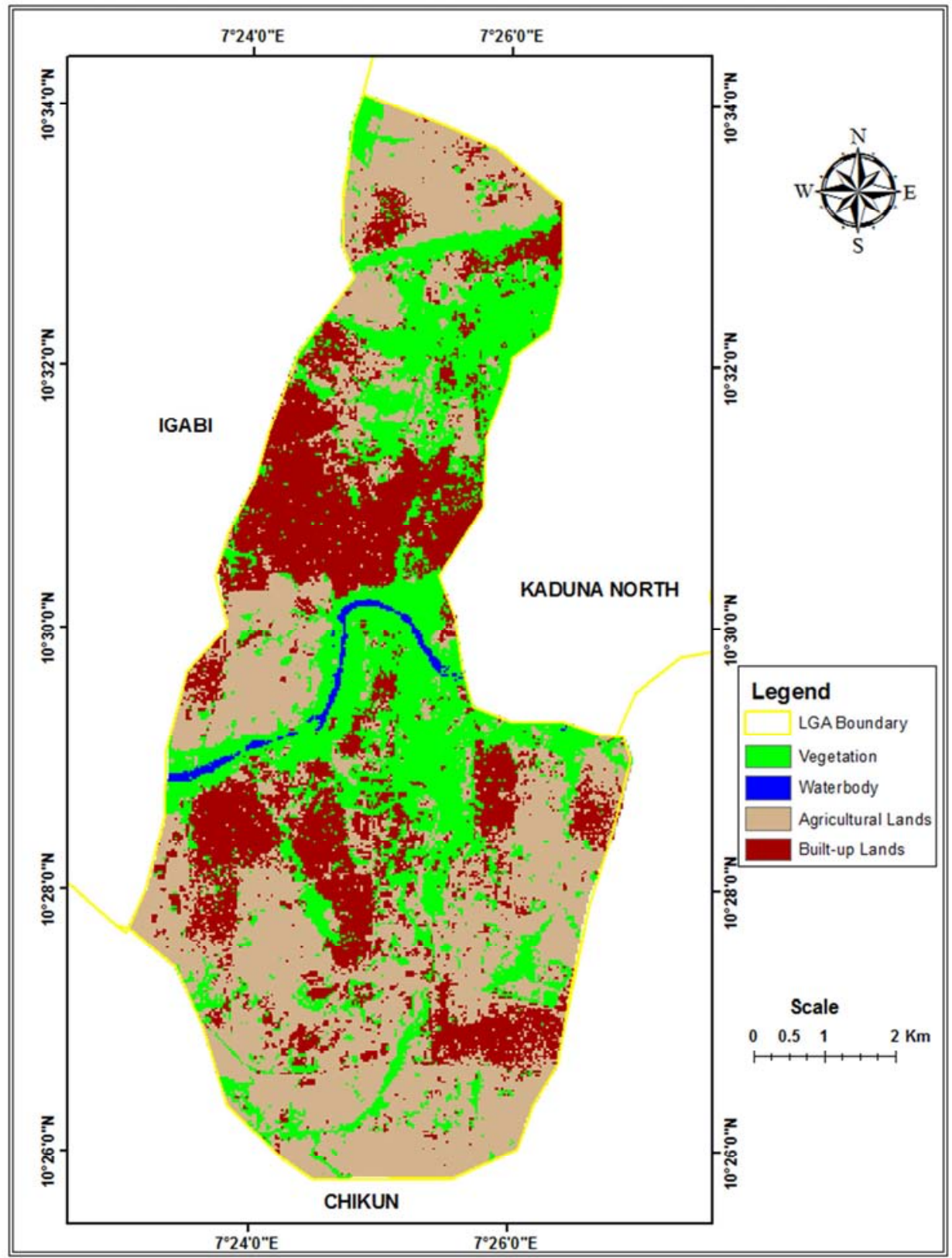

Source: Fieldwork (2018)

Figure 2. 1987 LULC Map of the Study Area. 


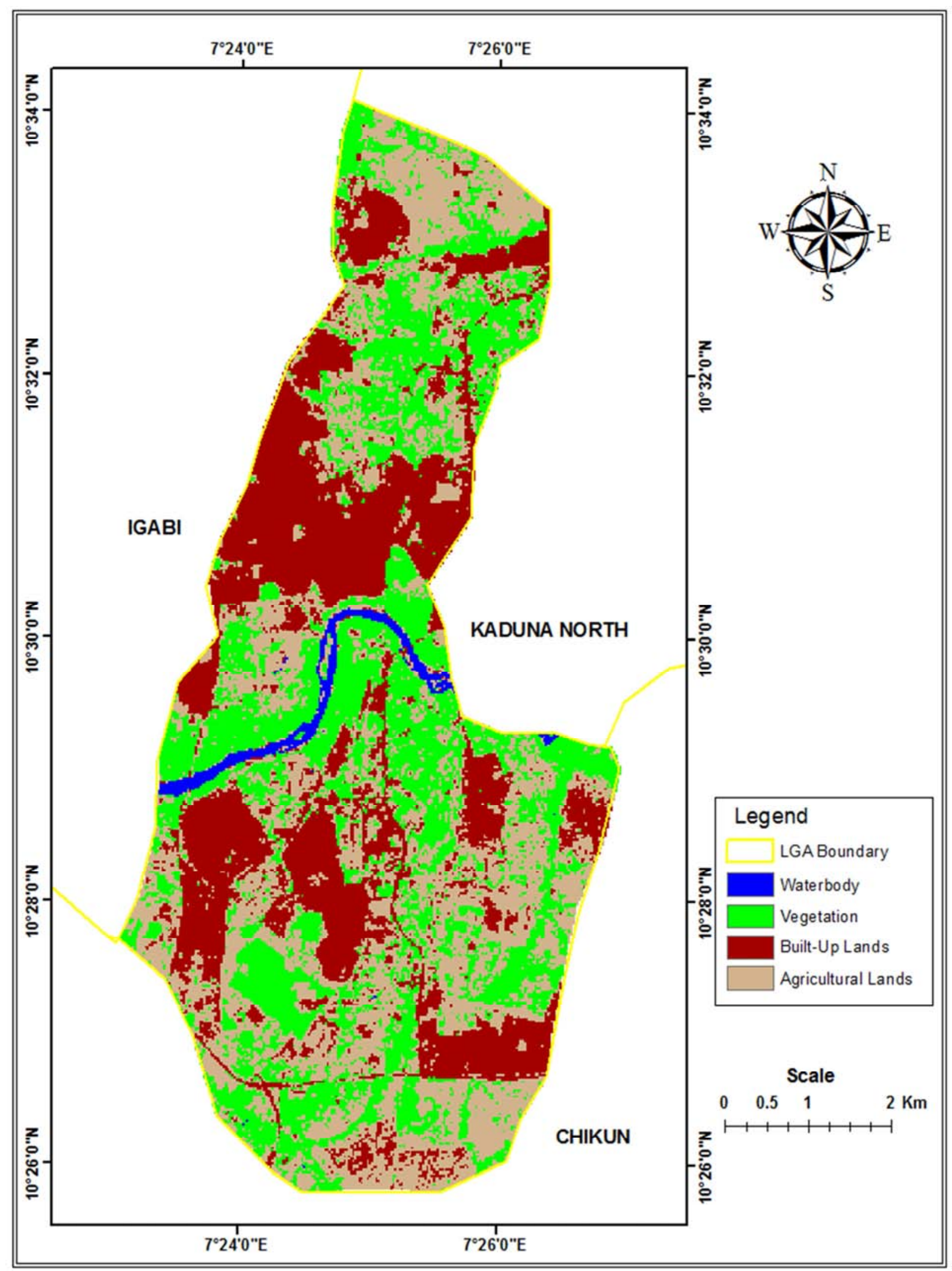

Source: Fieldwork (2018)

Figure 3. 2001 LULC Map of the Study Area. 


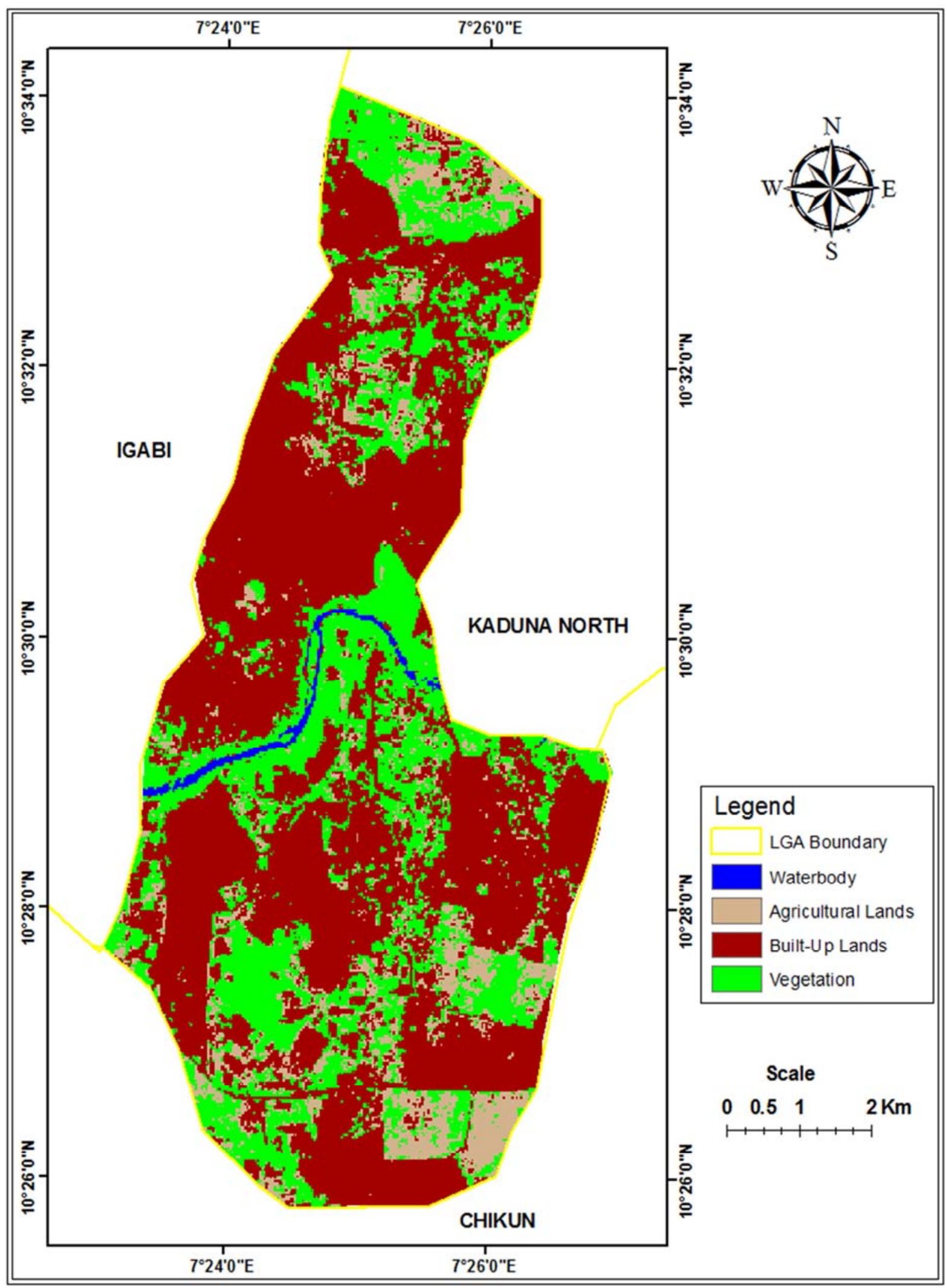

Source: Fieldwork (2018)

Figure 4. 2016 LULC Map of the Study Area. 


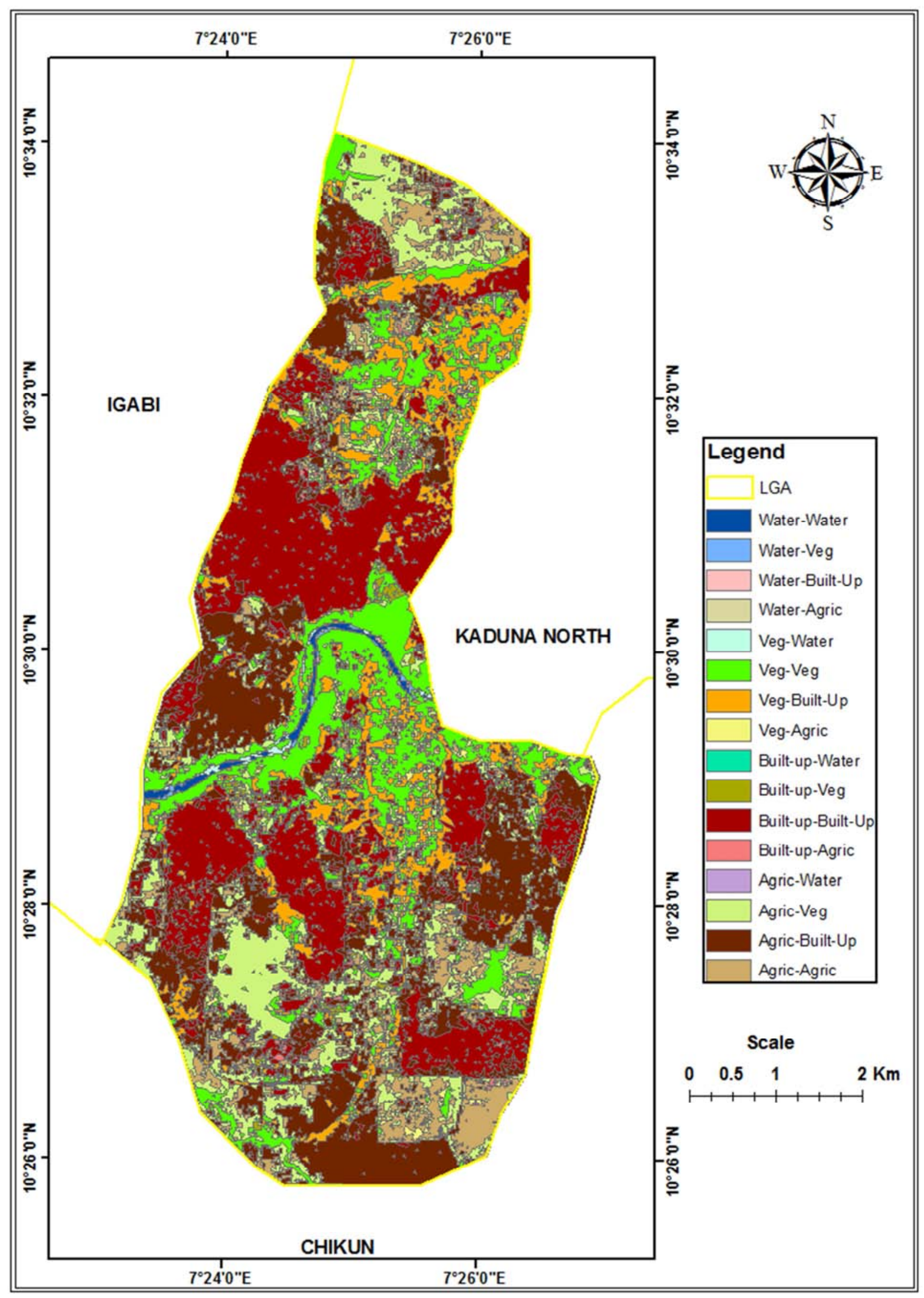

Source: Fieldwork (2018)

Figure 5. Overlay Map Showing LULC Transitions from 1987-2016. 


\section{Conclusion}

This study demonstrates the ability of Remote Sensing and Geographic Information System (GIS) integration to provide information on the LULC changes of an area, which in this study is Kaduna South LGA, of Kaduna State, Nigeria. The study has revealed that LULC changes have occurred in the study area. It further revealed that the built-up land use of the study area within the time under review has increased mainly at the expense of Agricultural land and Vegetation Cover. The LULC changes and Built-up area increase was validated or justified by the increase in population of the study area. The highest increase in the Built-up was noticed between 2001 and 2016; from $30.56 \%$ to $59.41 \%$.

\section{Recommendations}

The study therefore recommends that land use land cover (LULC) change detection study for the study area, and other local governments in Kaduna State and Nigeria as a nation. This should be carried out and updated biannually to create an enabling base for meaningful environmental planning and development in such areas.

\section{References}

[1] Quentin, F. B., Andrew, S. and Carole, H. (2006). Drivers of Land Use Change, Final Report: Matching Opportunities, Royal Melbourne Institute of Technology, Australia: ESAI Project.

[2] Liang, S., Shuey, C. J. and Russ, A. L. (2002). Narrowband to Broad Brand Conversion of Land Surface Albedo, Remote Sensing of Environment, 2002: 25-41.

[3] Zubair, A. O. (2006). Change Detection in Land Use and Land Cover Using Remote Sensing Data and GIS. Nigeria: University of Ibadan.

[4] Anderson, J. R., Ernest, E. H., John, T. R. and Richard, E. W. (1976). A Land Use and Land Cover Classification System for Use with Remote Sensor Data, United States Government Printing Office; Washington DC.

[5] Meyer, W. B., William, E. R., Turner, B. L. (1994). Modeling Landuse and Landcover as Part of Global Environmental Change. Climatic Change, 28 (1-2): 45-64.

[6] Ellis, E. (2010). Land-Use and Land-Cover Change, The Encyclopedia of Earth, Retrieved from http://www.eoearth.org/view/article/154143/

[7] Eludoyin, O. S., Wokocha, C. C. and Ayolagha, G. (2011). GIS Assessment of Land Use and Land Cover Changes in OBIO/AKPOR LGA., Rivers State, Nigeria, Research Journal of Environmental and Earth Sciences, 3 (4): $307-$ 313.

[8] Madugundu. R., Al-Gaadi, K. A., Patil, V. C. and Tola, E. (2014). Detection of Land Use and Land Cover Changes in Dirab Region of Saudi Arabia Using Remotely Sensed Imageries, Am. J. Environ. Sci., 10 (1): 8-18.
[9] Tilahun, A. and Teferi, B. (2015). Accuracy Assessment of Land Use Land Cover Classification Using Google Earth, Am. J. Environ. Protect, 4 (4): 193-198.

[10] Atubi, A. O., Awaritefe, D. O. and Toyon, A. B. (2018). Analysis of Land Use and Land Cover Change Characteristics in Warri Metropolis, Nigeria, International Journal of Development and Sustainability, 7 (3): 1143-1168.

[11] Holbrook, J. A. and Tudor, G. J. (1993). The Use of Remote Sensing and GIS Methods for Mapping Landcover Changes in Scotland, Environmental Audit Branch and Advisory Services Directorate, Scottish Natural Heritage.

[12] Asiyanbola R. A. (2014). Remote Sensing in developing country - Nigeria: An Exploration. Journal of Geography and Geology 6 (1): 110.

[13] Abiodun A. A., Chernikov, S., Camacho, S. (1990). Thematic Mapper data applications: Experience in a number of developing countries. Geocarto International 5 (1), 3-7, 1990.

[14] Opeyemi, Z. A. (2006). Change detection in landuse and landcover using remote sensing data and GIS (A case study of Ilorin and its environs in Kwara State). Department of Geography, University of Ibadan 176, 2006.

[15] Jafari, M., Zetabian, G. H., Khosravi, H. and Rostamizad, G. H. (2011). Change Detection and desertification based on multi-temporal satellite data: Case study: in Kashan Playa, Iran, Elixir International Journal Agriculture, 39: 4960-4963.

[16] Fichera, C. R., Giuseppe, M., Maurizio, P. (2012). Land Cover Classification and Change Detection Analysis Using Multitemporal Remote Sensed Imagery and Landscape metrics. European Jornal of Remote Sensing 45 (1), 1-18.

[17] Vittek, M., Brink, A., Donnay, F., Simonetti, D., Desclee, B. (2014). Landcover change monitoring using LandSat MSS/TM Satellite Image data over west Africa between 1975 and 1990. Remote sensing 6 (1), 658-676, 2014.

[18] Adeniyi, P. O. (1983). An Aerial Photographic Method for Estimating Urban Population, Photogrammetric Engineering and Remote Sensing, Journal of American Society of Photogrammetric, 49 (4): 545-560.

[19] Atubi, A. O. (2004). The Application of Remote Sensing in Monitoring Urban Land Dynamics in Victoria Island, Lagos, Nigeria, Journal of Empirical Research, 1 (2): 57-64.

[20] Narayanan, P. and Hanjagi, A. (2009). Land Use Change in Urban Bangalore Using GIS and Remotely Sensing, University of Craiova, Series Geography, Vol. 12 (New Series) NASA X-651-70-416.

[21] Ejemeyovwi, D. O. (2009). Landuse and Land Cover Mapping and Land Use Pattern in Abraka, Journal of Environmental Research and Policies, 4 (3): 68-77.

[22] Ogunbadewa, Y. E. (2012). Developing Natural Resources Database with Nigeriasat-1 Satellite Data and Geographical Information Systems, The Egyptian Journal of Remote Sensing and Space Sciences, 15: 207-214.

[23] Oriye, O. (2013). Urban Expansion and Urban Land Use in Ado Ekiti, Nigeria, American Journal of Research Communication, 1 (2): 128-139. 
[24] Ade, M. A. and Afolabi, Y. D. (2013). Monitoring urban sprawl in the Federal Capital Territory of Nigeria Using Remote Sensing and GIS Techniques, Ethiopian Journal of Environmental Studies and Management, 6 (1) 82-95.

[25] Monte, J. and Farhan, A. (2013). Land Use and Land Cover Change Analysis Using Satellite Remote Sensing: A Case Study of the Upper Niger Delta Region of Rivers State, Nigeria, European Journal of Geoengineering, 11: 1-9.
[26] National Population Commission (NPC) (2009). Federal Republic of Nigeria official Gazette, Lagos, the Federal Government Printers, 24 (94): 187. 